\title{
Effect of different levels of Dhania seed (Coriandrum sativum) on the performance of broiler
}

\author{
MM Rashid $^{1 *}$, MU Ahammad ${ }^{1}$, MS Ali ${ }^{1}$, MS Rana $^{2}$, MY Ali $^{2}$, N Sakib $^{2}$ \\ ${ }^{1}$ Department of Poultry Science, Bangladesh Agricultural University, Mymensingh 2202, Bangladesh; ${ }^{2}$ Poultry \\ Production Research Division, Bangladesh Livestock Research Institute, Savar, Dhaka
}

\begin{abstract}
A total of 72 as hatched Cobb 500 broilers were fed ad libitum on a diet with $0 \%, 0.5 \%, 1.0 \%$ and 1.5 $\%$ of coriander seed meal (CSM) to assess its feeding value. Treatment group with $1.5 \%$ of CSM significantly $(p<0.05)$ affected live weight of broilers at the age of 28 and 35 days. Among the dietary groups there is no significant difference in feed intake and feed efficiency. Meat yield characteristics especially abdominal fat level decreased significantly $(p<0.01)$ at $1.5 \%$ level of CSM. Cost of production per $\mathrm{kg}$ live broiler decreased when dietary inclusion level was increased. Profit per $\mathrm{kg}$ of live broiler was significantly $(p<0.05)$ increased with the increase levels of dietary CSM. These results suggest that the CSM could be considered as a potential natural growth promoter for poultry, and showed the best responses at a $1.5 \%$ level of inclusion. It was concluded that the supplementation of the coriander seed meal to broiler diet had beneficial effects on body weight gain, feed conversion ratio and carcass yield.
\end{abstract}

Key words: Coriander seed meal, live weight, feed intake, FCR, cost of production

Bangladesh Animal Husbandry Association. All rights reserved.

Bang. J. Anim. Sci. 2014. 43 (1): 38-44

\section{Introduction}

Synthetic non-nutritive feed additives are extensively used in poultry diet as growth promoter (GP) and prophylactic measures to overcome various diseases and stresses. The use of antibioticsm as GP in the chicken feed develops resistance in the pathogenic microorganisms that is a serious threat to human health (Botsglou and Fletouris 2000). Thus, the use of antibiotic as GP in the diet of birds and animals has been banned in many countries. For public concern about their residues in animal products and development of antibiotics resistance bacteria (Schwarz et al. 1998; Lee et al. 2004), force the nutritionist to search for an alternative to antibiotics. Aromatic plants as Coriander have become more important for their potential antimicrobial and stimulating effects on the animal digestive system. Coriandrum sativum (Dhania) used traditionally as anti-parasitic, anti-helminthic, analgesic, sedative, anti-septic and anti-diabetic properties (Lee et al. 2004, Matasyoh et al. 2009; Samojlik et al. 2010). In addition, it possess antimicrobial activity, (Singh and Sriroth 2002; Valero and Salmeron 2003), biological activities such as that of antioxidants (Miura et al. 2002) and hypocholesterolemicsm (Craig 1999). CSM has a stimulating effect on the digestive systems of poultry through the increasing production of digestive enzymes and by improving the utilization of digestive products. It also enhanced liver function (Langhout 2000; Hernandez et al. 2004).

As an aromatic plant, coriander is an annual species of the parsley family, native to the South Asian region and especially in Bangladesh. It is used primarily as a flavor agent in the food industry or as a spice in bread, cheese, curry, fish, meat, sauces, soup, and confections. The CSM is used as a medicine for thousands of years. The CSM has also appetizing and stimulatory effects on the digestion process (Çabuk et al. 2003). Moreover, herbs and spices are known for their preservation and medicinal value (Souza et al. 2005). CSM is considered as an herb and a spice. The seed of CSM contains $0.5 \%-1.0 \%$ essential oil rich in beneficial phytonnutrients including carvone, geraniol, limonene, borneol, camphor, elemol and linalool. Flavonoides compound in coriander include phenolic acid. It is also suggested that the volatile oils having antimicrobial properties against food borne pathogen such as Salmonella 
species. Coriandrum sativum can be used as whole plant and can be processed because of its perishable nature of leaves and to increase the palatability and as flavoring agent in different food preparations. Whole plant of coriander mainly fresh leaves and ripe fruits are used for culinary purposes. Coriander contains good amount of linoleic acid which is a good source of a-tocopherol and vitamin $\mathrm{K}$. Leaves of plant are rich source of vitamins while seeds are rich in polyphenols and essential oils. Coriander is also well known for its antioxidant, anti-diabetic, antimutagenic, anti-anxiety and antimicrobial activity along with analgesic and hormone balancing effect that promotes its use in foods due to numerous health benefits and its protective effect to preserve the food for longer period. (Bhat et al. 2010). Antioxidants stimulate the function of animal digestive systems to increase production of digestive enzymes through enhance liver functions (Hernandez et al., 2004) and therefore could be effectively utilized in poultry ration as feed additives. Essential oils in Coriander seed meal (CSM) have become more important for their potential. CSM is an unconventional feed stuff but with feed it has been recognized as an important tool for improving growth performance and feed conversion (Collington et al. 1990).

In recent years organic poultry is a relatively new expression in western countries which is also going to popular in our country. They use alternatives like organic acids, probioticsm, and medicinal plants in this method. These products have more fans in the customers (Ipu et al. 2006). As one of the alternatives, herbal extract is already used as feed supplements to improve growth in intensive management (Manzanilla et al. 2001). Plant extracts and spices as single compounds or as mixed preparations can play a role in supporting both performance and health status of the poultry (William and Losa 2001). With all these beneficial properties of CS, limited research has been done with Dhania plants and its seed to improve feed consumption (FC), feed conversion ratio (FCR) and carcass yield ( $\mathrm{CY}$ ) of broilers. From this standpoint, the present study was undertaken to assess the consequence of using CSM on productivity and meat yield of broilers and compare the growth and economic feasibility of using CSM as poultry feed.

\section{Materials and Methods}

The experiment was started with 72 Cobb 500 day old broilers and continued up to 35 days of age at Bangladesh Agricultural University (BAU) Poultry Farm, Mymensingh. A total of 72 as hatched Cobb 500 day old broilers were purchased from a commercial hatchery "Nourish Poultry and Hatchery Ltd" of Shreepur, Gazipur and CSM was purchased from local market of Mymensingh.

The broiler chicks were equally and randomly divided and distributed into four dietary treatments $(0,0.5,1.0$ and $1.5(\%)$ with three replications for each treatment. Each treatment consisted of 18 broilers and distributed into three replicated pens with 6 broilers in each replication. Dietary treatments were 4 in number. One $(0 \%)$ served as control while the other 3 diets were formulated with $0.5,1.0$ and 1.5 (\%). The broilers were given a starter and a finisher diet up to 35 days of age.

The experimental room was cleaned and disinfected first by bleaching powder solution prepared at the rate of $3 \mathrm{~g}$ per 5 liters of water and later with Vircon S (Antec International Limited, USA). After drying, the experimental house was divided into 12 equal sized pens, separated by bamboo materials and wire net partitions according to treatments and replications. Pen and wire net partitions were also disinfected by phenyl solution after cleaning and washing. The experiment was conducted in a gable type open sided tin-shed house. Proper management procedures were followed during experimental period and identical management practices were maintained. The house was partitioned into 12 pens using wire-net $(90 \mathrm{~cm}$ height) where a group of 6 birds were randomly allocated in each pen. The area of each pen was $(8 \times 7.5) \mathrm{sq} f \mathrm{ft}$ and was allotted for broilers. Therefore, floor space for each broiler was 1.46 $\mathrm{sq} \mathrm{ft}$ for comfort ability of broilers during winter. One tube $(90 \mathrm{~cm} \times 11.5 \mathrm{~cm} \times 6 \mathrm{~cm})$ feeder and one pot drinker with a capacity of one litter were provided in each pen up to 35 days. Feeders were cleaned every week and drinkers were cleaned every morning. Broilers had ad libitum access to diets and fresh drinking water. Saw dust was used as litter material at a depth of $5 \mathrm{~cm}$. After 


\section{Dhania seed in broiler diet}

third week previous litter was mixed up with new dry saw dust. Every two days interval litter was stirred to prevent ammonia gas and maggot formation. A vaccination schedule was followed during the experimental period. All of the experimental broilers were vaccinated against New Castle disease (Ranikhet) and Infectious Bursal Disease (IBD) (Gumboro) at the age of day 4 th and 12 th respectively. All the vaccines were administered as per recommendation of the manufacturer (Advance Animal Science Co. Ltd., Dhaka, Bangladesh) one drop in each eye at the cooler part of the day (morning).

Locally available ingredients were used to formulate diet for broilers. The diets prepared by hand mixing. All ingredients except soybean oil were purchased from the local market of Mymensingh. Major ingredients were thoroughly mixed at first and then micro-ingredients. The diets were prepared with 4 different levels of 0 , $0.5,1.0$ and $1.5 \%$ CSM, where $0 \%$ was considered as control. Two types of diets; starter and finisher were supplied to the broilers. In first 16 days starter diet was supplied and then from 17-35 days finisher diet was supplied to the broilers. The nutrients requirement of broilers was satisfied according to BSTI standard.

The chicks were brooded up to 7 days. For conducting the experiment in winter season at early period the temperature was lower than the required brooding temperature. Temperature was maintained at $30^{\circ} \mathrm{C}$ as brooding temperature which decreased gradually in subsequent weeks ( $2.5^{\circ} \mathrm{C} /$ week until the birds were adjusted to environmental temperature $\left(15-17^{\circ} \mathrm{C}\right)$. To maintain brooding temperature an electric bulb (100 watt, 1 in each pen) was used up to 14 days of age. After then one 60 watt bulb was replaced between two cages instead of 100 watt bulb to maintain optimum temperature. Broilers were exposed to 24 hours continuous light in first 7 days. Then from 8 days 23 hours light and 1 hour dark is provided up to marketing age. Half an hour to one hour of darkness at night was provided so the birds could get accustomed to darkness. That way in the event there was a power outage at night the birds would not panic.

Strict bio-security measures were taken during the experiment. The bushes around the shed were cleaned and lime was spread over. Personnel entrance was restricted except assigned worker, researcher, supervisor and cosupervisor. Before entrance, shoes were changed and feet were dipped in a footbath containing disinfectant solution (potassium permanganate). The footbath was at the entrance point of the experimental house. No birds were died during the entire experimental period.

At the end of the experiment, a total of 12 broilers; one from each replicate group weighing average of pen weight were selected and sacrificed to determine the meat yield characteristics. Feed was withdrawn 12 hours prior to killing the birds. After complete bleeding, the slaughtered broilers were immersed in water heated to $51-55^{\circ} \mathrm{C}$ for 120 seconds in order to loosen the feathers of the carcasses.

Final processing was performed by removal of the head, shanks, viscera, oil gland, kidneys and lungs of the carcasses. Heart and liver were removed from the remaining viscera by cutting them loose. As soon as these were removed the gall bladder was removed from the liver and the pericardial sac and arteries were excised from the heart. The gizzard was removed by cutting it loose in front of the proventiculus and then cutting both incoming and outgoing traces. Then, it was split open with knife, emptied and washed and the lining was removed by hand.

Blood weight was calculated by deducting the slaughtered weight from the live weight of broilers after complete bleeding. Feather weight was calculated by deducting the complete defeathering broiler weight from the slaughtered weight of broilers. The weight of head, neck, viscera, heart, liver, gizzard, thigh meat, drumstick meat, back meat, and breast meat were determined individually by using the sensitive weighing balance. Dressing yield was calculated by subtracting the weight of blood, feathers, viscera and shank from the live weight. Giblet weight was the total weight of liver, heart, gizzard, lung and spleen. Dressed weights of broilers were calculated deducting the weights of head, neck and giblet from carcass.

Cost of production was calculated based on the expenses of chicks, feed and other costs (other 
costs included vaccine, labour, transport, litter, electricity and water supply etc). Feed cost was calculated on the basis of market price of the ingredients. Litter cost was calculated on the basis of market price of the saw dust.

All recorded and calculated data were statistically analyzed using analysis of variance technique by a computer using a SAS statistical computer package program in accordance with the principles of completely randomized design. Least significant differences were calculated to compare variations among diets where ANOVA showed significant differences.

\section{Results and Discussion}

Generally live weights increased with increasing the age of birds (Table 1 ). Live weights of broilers were similar on levels of at 7, 14 and 21 days of age. However, significant differences appeared at $28(p<0.05)$ and 35 days of age $(p<0.01)$ where live weight increased in linear pattern at the increasing levels of dietary coriander seed meal (CSM). A gradual increase in live weight at 28 and 35 days of age (finishing period) for increasing dietary CSM is supported by Farah (2011), Jafar (2011), Ansari et al. (2006), Cossu et al. (2002). They reported that broilers fed on $1.5 \%$ to $2.0 \%$ coriander had higher $(p<0.05)$ live body weight and body weight gain. Other researchers reported that broilers supplemented with diet 3.0 or $4.0 \%$ CSM showed higher ( $P$ $<0.05$ ) live body weight (Guler et al. 2005). The improvement in weight gain of the broilers using CSM in their diets may probably be for its antioxidant properties which act as natural growth promoter.

\section{Feed intakes ( FI)}

There was no difference found on FI which could be explained by different dietary levels of CSM (Table 1 ). With the advancement of age the FI increased at different dietary CSM groups. It was found that at $0.5,1$ and $1.5 \%$ dietary CSM consuming groups are eventually more or less similar to control $(0 \%)$ CSM consuming group (Table 1). Feed Intake (FI) up to 35 days of the experiment was more or less similar. Ansari et al. (2006) observed that $\mathrm{FI}$ up to 42 days of age with the advancement of DCSM becomes significant. FI decreases in the conducted experiment probably for change of weather. The experiment was conducted when the temperature was comparatively higher but in the finishing period it was winter. It may be one of the causes to vary in feed intake of broilers.

Table 1. Effect of dietary levels of CSM diets on live weight, feed intake and feed efficiency of broilers at different ages

\begin{tabular}{|c|c|c|c|c|c|c|}
\hline \multirow{2}{*}{ Parameter } & \multirow{2}{*}{$\begin{array}{l}\text { Age } \\
\text { (d) }\end{array}$} & \multicolumn{4}{|c|}{ Dietary coriander seed (\%) } & \multirow{2}{*}{ Sig. } \\
\hline & & $\overline{0}$ & 0.5 & 1.0 & 1.5 & \\
\hline \multirow{6}{*}{$\begin{array}{l}\text { Live weight } \\
(\mathrm{g} / \mathrm{kg})\end{array}$} & 0 & 41.7 & 41.8 & 41.8 & 41.3 & NS \\
\hline & 7 & 112.0 & 114.3 & 115.7 & 117.0 & NS \\
\hline & 14 & 267.7 & 281.3 & 289.3 & 291.7 & NS \\
\hline & 21 & 468.3 & 492.7 & 498.7 & 510.0 & NS \\
\hline & 28 & $730.0^{\mathrm{b}}$ & $770.7^{\mathrm{ab}}$ & $781.7^{a}$ & $816.7^{a}$ & * \\
\hline & 35 & $1030.0^{c}$ & $1077.0^{\mathrm{bc}}$ & $1120.0^{\mathrm{ab}}$ & $1163.0^{a}$ & ** \\
\hline & 7 & 105.0 & 105.0 & 104.0 & 108.0 & NS \\
\hline Feed & 14 & 248.0 & 260.0 & 268.0 & 260.0 & NS \\
\hline intake & 21 & 355.0 & 363.0 & 353.0 & 368.0 & NS \\
\hline \multirow[t]{3}{*}{$(\mathrm{g} / \mathrm{kg})$} & 28 & 493.0 & 507.0 & 513.0 & 543.0 & NS \\
\hline & 35 & 653.0 & 647.0 & 667.0 & 680.0 & NS \\
\hline & 7 & 1.50 & 1.5 & 1.41 & 1.43 & NS \\
\hline Feed & 14 & 1.60 & 1.6 & 1.55 & 1.49 & NS \\
\hline conversion & 21 & 1.81 & 1.7 & 1.69 & 1.69 & NS \\
\hline \multirow[t]{2}{*}{ ratio (FCR) } & 28 & 1.93 & 1.8 & 1.82 & 1.78 & NS \\
\hline & 35 & 2.20 & 2.2 & 1.99 & 1.98 & NS \\
\hline
\end{tabular}

Means with different superscript(s) in the same row differed significantly; $* *, \mathrm{p}<0.01 ; *, \mathrm{p}<0.05$; $\mathrm{P}>0.05$, NS, non significant

\section{Feed conversion ratio ( FCR)}

FCR of broilers on different dietary CSM did not differ at 35 days of age. It was found that all dietary CSM- $0.0,0.5,1.0$, and $1.5 \%$ were more or less similar during the experimental period. Feed conversion appeared to remains more or less similar in the entire dietary CSM groups $(0$, $0.5,1.0$ and $1.5 \%$ ) irrespective of age. Deepa and Anuradha (2009) reported that up to $2 \%$ inclusion level of DCSM, FCR remained unchanged. It may be due to very insufficient level of CSM in the formulated diet. The result contradicts with the previous reports of Farah (2011), who reported higher CSM containing diet had higher FCE and shows also higher body weight. These dissimilarities may happen probably for the impact of environmental insult.

\section{Meat yield characteristics}




\section{Dhania seed in broiler diet}

Dietary CSM did not modify the dress yield, breast meat, thigh meat and wing meat which could be explain for the variation of CSM (Table $2)$. Highly significant differences $(p>0.01)$ were found for the percentage of abdominal fat and spleen and live weight among all the dietary groups.

Table 2. Effect of feeding coriander seed meal diets on meat yield characteristics of broilers at different ages

\begin{tabular}{|c|c|c|c|c|c|}
\hline \multirow[t]{2}{*}{ Variables } & \multicolumn{4}{|c|}{$\begin{array}{l}\text { Dietary coriander seed meal (DCSM) } \\
(\%)\end{array}$} & \multirow[t]{2}{*}{ Sig } \\
\hline & $\overline{0}$ & 0.5 & 1.0 & 1.5 & \\
\hline Live weight (g/broiler) & 969.3 & 1037.0 & 1109.0 & 1211.7 & ** \\
\hline Blood (\%) & 4.9 & 5.5 & 5.11 & 5.42 & NS \\
\hline Feather (\%) & 7.1 & 6.9 & 6.70 & 6.19 & NS \\
\hline Breast meat (\%) & 15.9 & 15.9 & 15.01 & 14.05 & NS \\
\hline Thigh meat (\%) & 6.1 & 6.1 & 5.35 & 5.90 & NS \\
\hline Thigh bone (\%) & 1.3 & 1.1 & 1.05 & 0.99 & NS \\
\hline Drumstick meat (\%) & 3.3 & 2.9 & 2.85 & 2.62 & NS \\
\hline Drumstick bone (\%) & 1.7 & 1.60 & 1.36 & 1.31 & NS \\
\hline Wing meat (\%) & 2.1 & 1.90 & 1.84 & 1.60 & Ns \\
\hline Wing bone (\%) & 1.6 & 1.43 & 1.20 & 1.31 & NS \\
\hline Abdominal fat (\%) & $1.7^{\mathrm{a}}$ & $1.43^{b}$ & $1.14^{c}$ & $1.19 \mathrm{bc}$ & ** \\
\hline Gizzard (\%) & 1.7 & 1.73 & 1.74 & 1.89 & NS \\
\hline Head (\%) & 2.7 & 2.79 & 2.69 & 2.73 & NS \\
\hline Heart (\%) & 0.4 & 0.51 & 0.44 & 0.47 & NS \\
\hline Liver (\%) & 2.6 & 2.45 & 2.44 & 2.12 & NS \\
\hline Neck (\%) & 2.5 & 2.18 & 2.28 & 2.53 & NS \\
\hline Skin (\%) & 13.6 & 13.33 & 12.04 & 11.63 & NS \\
\hline Spleen (\%) & $0.0108^{a}$ & $0.0102^{a}$ & $0.0089 \mathrm{~b}$ & $0.0087 \mathrm{~b}$ & ** \\
\hline Shank (\%) & 5.2 & 4.66 & 4.37 & 4.36 & NS \\
\hline Dressing yield (\%) & 53.6 & 53.55 & 54.61 & 52.33 & NS \\
\hline
\end{tabular}

Means with different superscript(s) in the same row differed significantly; **, $\mathrm{p}<0.01 ; *, \mathrm{p}<0.05 ; \mathrm{P}>$ 0.05 , NS, non significant

For increasing the CSM level decreasing the fat level and vice versa in a linear fashion. Significant differences $(p<0.01)$ also observed at spleen. Highest significance was observed at control (0 $\%)$ and $0.5 \%$ CSM containing diet group. Sahoo et al. (2008) observed there was no difference ( $p>0.05$ ) among the average dressing yield, heart, gizzard, liver, breast meat drumstick meat and thigh bone of broilers fed diets with or without supplementation of CSM (Dania). There was highly significant differences $(p<0.01)$ in abdominal fat percentage with the dietary $1.5 \%$ Dania group. Many investigators found that dietary advancement of CSM between 1.5 to $4 \%$ decreases the cholesterol level (Aissaoui et al.
2011; Dhanapakiam et al. 2008). The highest significant difference observed $(p<0.01)$ in abdominal fat percentage for lipolytic effect of CSM. In addition the relatively higher live weight may have an additional effect in live weight gain attributed to slaughter weight.

\section{Production cost and profit}

Feed cost in different dietary CSM groups were more or less similar, whereas total production cost per $\mathrm{kg}$ broiler was lower in $1.5 \%$ CSM than control (0\%) CSM group ( $p<0.05)$ (Table 3). Sale (Taka/ broiler) appeared significantly different $(p<0.01)$ in $1.5 \%$ dietary CSM level though sale (Taka/kg broiler) were more or less similar in all other treatments. Profit per broiler and per $\mathrm{kg}$ broiler was highest on $1.5 \%(p<0.05)$.

Table 3. Effects of dietery coriander seed meal at $0, \quad 0.5, \quad 1.0$ and $1.5 \%$ on cost of production and profit of broilers

\begin{tabular}{|c|c|c|c|c|c|}
\hline \multirow[t]{2}{*}{ Parameters } & \multicolumn{4}{|c|}{ Dietary Coriander Seed (\%) } & \multirow[t]{2}{*}{ Sig. } \\
\hline & 0 & 0.5 & 1.0 & 1.5 & \\
\hline $\begin{array}{l}\text { Feed cost } \\
\text { (Tk./kg broiler) }\end{array}$ & 33.20 & 33.40 & 33.45 & 33.50 & NS \\
\hline $\begin{array}{l}\text { Production cost } \\
\text { (Tk./broiler) }\end{array}$ & 99.83 & 98.22 & 96.66 & 96.05 & NS \\
\hline $\begin{array}{l}\text { Production cost } \\
\text { (Tk./kg broiler) }\end{array}$ & $97.00^{a}$ & $91.30^{a b}$ & $86.40^{\mathrm{bc}}$ & $82.60^{c}$ & * \\
\hline Sale (Tk./broiler) & $123.60^{c}$ & $129.20^{\mathrm{bc}}$ & $134.40^{\mathrm{ab}}$ & $139.60^{a}$ & ** \\
\hline Sale (Tk./kg live broiler) & 120.00 & 120.00 & 120.00 & 120.00 & NS \\
\hline Profit (Tk./broiler) & $23.80^{c}$ & $31.00^{\mathrm{bc}}$ & $37.70^{\mathrm{ab}}$ & $43.50^{a}$ & * \\
\hline Profit (Tk./kg broiler) & $23.00 c$ & $28.70^{b c}$ & $33.60^{a b}$ & $37.40 \mathrm{a}$ & * \\
\hline
\end{tabular}

Means with different superscript(s) in the same row differed significantly; **, $\mathrm{p}<0.01 ; *, \mathrm{p}<0.05$; $\mathrm{P}>$ 0.05 , NS, non significant

The experimented results for cost analysis was coincide with Maust et al. (2005) who reported supplementation of CSM at $1.5 \%$ diet was more beneficial and profitable in broiler production than that of $0.5 \%$ level. They also reported that the broilers fed diets with added CSM, fetched more profit than those using rations without supplementation of this herbal growth promoter. Increase in the profit margin of the broilers fed diets containing herbal growth promoters may be attributed to the better efficiency of feed utilization. Higher CSM (Dhania) containing diet leads to greater body weight which ultimately results higher profit. 


\section{Conclusion}

Based on the results obtained in current study, it has been concluded that the coriander seed meal can be included at 1.0 and $1.5 \%$ levels in the diet as natural growth promoter for boiler to improve feed consumption, feed conversion ratio and carcass yield.

\section{References}

Aissaoui A, Zizi S, Israili ZH, Lyoussi B (2011). Hypoglycemic and hypolipidemic effects of Coriandrum sativum L. in Quail. Egyptian Poultry Science J ournal, 17: 77-83.

Ansari MA, Ahmed S, Haider NI (2006). Coriandrum sativum A non-conversional herbal option for the management of seasonal allergic rhinitis. Pakistan Journal of Pharmacology, 23: 31-35.

Bhat S, Kaushal P, Kaur M, Sharma HK (2010). Coriander (Coriandrum sativum L.): Processing, nutritional and functional aspects. Amity Institute of Food Technology (AIFT), Amity University Campus, Noida-2010, India.

Botsglou NA, Fletouris DJ (2001). Drug residues in foods. Pharmacology, food safety and analysis. New York, Marcel Dekker, pp: 541-548.

Cabuk MA, Alcicek M, Bozkurt N, Imer RS (2003). Antimicrobial properties of the essential oils isolated from aromatic plants and using possibility as alternative feed additives. National Animal Nutrition Congress, 18-20 September.

Chithra V, Leelamma S (2010). Coriandrum sativum effect on lipid metabolism in 1, 2dimethyl hydrazine induced colon cancer in broiler. International Journal of Poultry Science 9: 968-971.

Collington GK, Park DS, Armstrong DG (1990). Anti-oxidant properties of coriander seed in poultry. Brazilian Journal of Nutrition, 64: 59- 70.

Cossu ME, Lazzari GL, Warwkievicz M, Danelon JL, Cumini ML (2002). Use of Coriandrum sativum L. grain in broiler diets. Influence on meat taste and muscle fatty acid composition. Poultry Science, 2: 446-448.
Craig OL (1999). Efficacy of coriander in lowering blood cholesterol level in broiler. Animal Feed Science and Technology, 3: 345-380.

Deepa B, Anuradha CV (2009). Effect of Antioxidant potential of Coriandrum sativum L. seed extract on broiler. Indian Journal of Animal Production and Management, 6: 115-118.

Dhanapakiam P, Joseph JM, Ramaswamy VK, Moorthi M, Kumar AS, (2008). The Cholesterol Lowering Property of Coriander Seeds (Coriandrum sativum): Mechanism of Action. Egyptian Poultry Science J ournal, 12: 36-39.

Farah K, J aff AL (2011). Effect of Coriander Seeds as Diet Ingredient on Broiler Chicks Raised under High Ambient Temperature. International Journal of Poultry Science, 10: 82-86.

Guler ON, Ertas M, Ciftci B, Dalkihe TS (2005). Effect of Feeding Coriander (Coriandrum sativum, L.) on Egg Production Performance and Nutrient Retention in Laying Japanese Quails. Journal of Applied Animal Research, 30: 181-184.

Hermandez FJ, Madrid V, Garcia J, Orengo M D, Megias K (2004). Influence of tow plant extract on broiler performance, digestibility and digestive organ size. Poultry Science, 83: 169-174.

Hernandez F, J Madrid V Garcia, J Orengo, MD Megias (2004). Influence of two plant extract on broiler performance, digestibility and digestive organ size. Poultry Science, 83: 169-174.

I pu MA, Akhtar MS, Anjumi MI, Raja ML (2006). Effects of dietary coriander seed on blood and cholesterol level in broiler. Pakistan Veterinary Journal. 26: 144-148.

J afar Pish Jang (2011). Effect of different levels of coriander seed on performance of broiler Chickens, Annals of Biological Research 2: 578-583.

Langhout P (2000). New additives for broiler chickens. World's Poultry Science Journal, 16: 22-27.

Lee KWH, Evert's AC, Beynen (2004). Essential oils in broiler nutrition. International J ournal of Poultry Science, 3: 738-752.

Manzanilla EG, Baucells F, Kamel C, Morales J, Perez JF, Gasa J (2001). The nutritive value of dried coriander seed in the diet of 


\section{Dhania seed in broiler diet}

broiler. Journal of Animal Science. 1: 4753.

Matasyoh JC, Maiyo ZC, Ngure RM, Chepkorir R (2009). Chemical composition and antimicrobial activity of the essential oil of Coriandrum sativum. Food Chemistry 113: 526-529.

Maust LE (2005). Nutritive value of coriander seed for chicks, Poultry Science, Journal of Food and Agriculture, 1: 11-15.

Miura ZK, Nweke FI, Poulson R (2002). Coriander Production Trends in South African Region in a Developing Economy, Agricultural Production Status of Accara, 11: 311-321.

Sahoo SK, Naskar SK, Panda BK, CM, Padhi NE (2008). Performance of broiler on replacement of maize with different spices. Izatnagar, India: Animal Nutrution Association, 8: 121-126.

Samojlik I, Lakic N, Mimic- Dukic N and Bozin B (2010). Antioxidant and hepatoprotective potential of International Food Research Journal 19: 1253-1260.

Schwarz MH, Jackson SH, Kompiang IP (1998). The nutritional value of Corinder leaf and its seed in poultry feeds. Malaysian Research Bulletin, 6: 180-185.

Singh RA, Sriroth KR (2002). Poultry Production (3rd edition), Kalyany Publishers, New Delhi, Ludhiana.

Souza EL, Stamford TIM, Lima EO, Tarajano Fillo JBM (2005). Antimicrobial effectiveness of spices: An approach for use in food conversion system. Brazilian Biology, 48: 1516-8913.

Valero RG, Salmorn S (2003). The nutritive value of coriander leaf. Poultry Science, 48: 243251.

William P, Losa R (2001). Effects of coriander seed and Nigela on blood parameters of broiler. World's Poultry Science Journal. 17: $14-15$. 